\title{
Grenfell Tower fire - a tragic case study in health inequalities
}

\author{
R. G. Watt ${ }^{1}$
}

In brief

Highlights that the recent Grenfell Tower fire has raised fundamental policy questions about safety regulation in the UK.
Suggests that, seen through a public health perspective, this tragic incident is ultimately about social inequality in the UK.
Suggests that as general and oral health inequalities are caused by the same underlying factors, the lessons learnt from this tragedy have relevance to oral health professionals committed to tackling social inequalities.

At least 80 people died in the recent Grenfell Tower fire in Kensington and Chelsea, West London. This incident has provoked much anger, debate and reflection on how such a tragedy could happen in London, one of the richest cities in the world. Seen through a public health lens, this disaster is ultimately about social inequality in modern Britain. Kensington and Chelsea is a deeply divided community, where many billionaires and very wealthy people live cheek by jowl with poor and disenfranchised people struggling to make ends meet. It is therefore not a surprise that such a terrible incident should happen in this socially unequal setting where very stark health inequalities already exist. This paper explores some of the broader underlying factors that may have contributed to this tragedy, the political determinants of health. As these factors are linked to both general and oral health inequalities, the lessons learnt from this incident have direct relevance and salience to oral health professionals concerned about tackling social inequalities in contemporary society.

Margaret Whitehead's classic definition of health inequalities as health differences that are 'avoidable, unjust, unfair and unacceptable, ${ }^{1}$ perfectly describes the deaths caused by the recent Grenfell Tower fire in West London. On 12 June 2017 a fire started by a faulty fridge freezer in a fourth floor flat in Grenfell Tower, a 24-storey tower block in the Royal Borough of Kensington and Chelsea turned into an inferno in the space of minutes trapping many families, with at least 80 people believed to be dead - although the final death toll is expected to be much higher.

Following the tragic fire many commentators have been asking how such a terrible event could happen in twenty-first century London, one of the richest cities in the world. The UK used to be world renowned for its

'Department of Epidemiology and Public Health 1-19 Torrington Place, London WC1E 6BT

Correspondence to: Richard Watt

Email: r.watt@ucl.ac.uk

Refereed Paper. Accepted 10 August 2017

DOI: 10.1038/sj.bdj.2017.785 stringent health and safety record. What has gone so badly wrong for this event, the worst fire in the UK for over a century, to happen? The government has appointed Sir Martin Moore-Bick to lead a public inquiry into the fire and the police are conducting a criminal investigation, but these may take months or even years to report. There is a groundswell of pressure from the surviving victims, the local community and many others for answers to why this tragedy happened. Key questions that need answers include: What were the underlying causes behind this incident? How did public services respond to the unfolding events on 12th June? What are the longer-term policy implications to ensure that this terrible event is not repeated? It has been argued that this disaster is ultimately about social inequalities in modern Britain - a tragic tale of political ineptitude and neglect, disenfranchised and marginalised families ignored by those in positions of power and authority, and public services unable to cope with the immediate and longer-term consequences of the fire.,
Although it is important to investigate the potential role of the recently placed cladding and other technical issues in the fire, it is essential that the broader underlying factors of this tragedy are investigated and uncovered. Several years ago the British Medical Journal banned the word 'accidents' in any of its scientific publications, preferring instead the use of the term injury. ${ }^{4}$ This was principally because the word 'accident' strongly implied that the event leading to the injury happened by chance, at random. Major incidents like the Grenfell Tower fire do not happen by chance, they are caused by a web of inter-related factors that ultimately lead to the tragedy - the political determinants or as Rose (2008) described, 'the causes of the causes. ${ }^{5}$

The Royal Borough of Kensington and Chelsea is the richest borough in London with a staggeringly high mean income of $£ 116,000$ per year. ${ }^{6}$ It is home to many billionaires (hence the extremely high mean income) and the average cost of a property is over $£ 2$ million. However, it is also characterised by stark economic and 
social inequality. Wards in the north of the borough, including Notting Barnes (the ward where Grenfell Tower is located), have higher rates of low income households, child poverty and registered homeless people compared to the London average. Although overall life expectancy is higher than the England average, shocking health inequalities exist in this area of West London. For example, life expectancy is 16 years lower for men living in the most deprived areas of Kensington and Chelsea compared to the least deprived. ${ }^{7}$ Although the personal details of the victims are not, as yet fully available, it is very apparent that the families affected were mostly from disadvantaged and marginalised backgrounds, including many recent migrants and refugees. National data have shown that injury-related deaths are strongly associated with levels of deprivation, particularly deaths caused by fires. Children living in households where parents never worked or are long-term unemployed are 38 times more likely to die in a fire than children living in families with professional parents. ${ }^{8}$ The death toll in Grenfell Tower provides yet more evidence on the grim statistics of deprivation, disadvantage and mortality.

Kensington and Chelsea local authority have been heavily criticised for many years as being out of touch, detached and elitist in nature, only concerned with the interests of their wealthy residents. Although $£ 8.7$ million was spent on refurbishing Grenfell Tower in 2016, almost immediately, residents voiced concerns about the fire risks in the newly refurbished building. The Grenfell Action Group, acting on behalf of the local residents complained to the council on ten separate occasions over concerns of the fire hazards in the tower block. All these warnings were totally ignored by those in positions of power. No one listened to the residents' fears. The local population were therefore powerless in their attempts to improve the safety of their homes. Although the council has amassed a budget reserve in excess of $£ 274$ million, during the building refurbishment a decision was made to use cheaper quality cladding material to save an estimated $£ 290,000$. This is the cladding material that is suspected of rapidly spreading the fire on the exterior of the building due to its combustible nature - a material that is not permitted for use in tall buildings in Germany and many other European countries. Major concerns have also been voiced about the council's immediate response to the unfolding events on 12 June. As the magnitude of the tragedy became apparent and hundreds of surviving victims and residents were in urgent need of help, both practical and emotional, the local politicians seemed incapable of providing the necessary assistance and support. It took days before an organised and effective response was mobilised. Eventually, amid a media frenzy the Conservative leader of the council, Nicholas Paget-Brown, took responsibility for the failings of the council and resigned with immediate effect.

It has also emerged that although fire crews from the London Fire Brigade managed to bravely save the lives of over 250 people from the inferno, the London fire service did not have a sufficiently tall ladder to deal with a fire in a 24 -storey tower block and had to borrow a $42 \mathrm{~m}$ firefighting platform from Surrey fire service, causing a critical delay in their response and management of the fire. It seems bizarre in the extreme that London, with so many tall buildings and many others under construction, does not have access to the appropriate equipment to deal with fires in tower blocks.

How have national policies contributed to the events in Grenfell Tower? For decades governments of all political persuasions have failed to address the housing crisis in the UK. There is an acute shortage of affordable housing, particularly in the south of England where the costs of the private rental sector are beyond the reach of many. The right to buy policy introduced by Margaret Thatcher in the 1980s has greatly diminished the social housing stock across the country and very few new social housing developments have since been built. Increasingly, social housing has been perceived as the 'dumping ground' for the most marginalised and disadvantaged in society, and the residents vilified as 'scroungers' and social outcasts - see the portrayal of social housing residents in television programmes such as 'Benefits Street'. This combined with a backlash against a health and safety 'culture' has seen a steady relaxation of building regulations and controls. Deregulation, privatisation and the outsourcing of public services are all part of a political neo-liberal ideology that has influenced government policy in many countries across the globe over the last 30 years.

Government regulation is perceived as bad, interfering and stifling red tape. Freed up market forces are seen as the way forward in encouraging enterprise and innovation. In addition, since 2010, austerity measures introduced by the coalition government and continued by the Conservative administration have seen dramatic reductions in local authority budgets including housing inspection and maintenance services. Cuts to the legal aid budget have also had a significant effect in greatly limiting access of legal support for low-income people. With appropriate legal representation perhaps the safety concerns of the Grenfell Tower residents would have been taken seriously by those in positions of authority and the necessary improvements made to avoid the tragic events in June. All these policies have undoubtedly played a role in creating a deeply fractured and unequal society where the most vulnerable and disadvantaged live in unsafe conditions.

The dramatic events at Grenfell Tower may seem very remote and unconnected to oral health. However, the underlying causes and pathways for both general and oral health inequalities are shared. ${ }^{9}$ What lessons, therefore, need to be learnt from this tragedy? Seen through a public health lens, the Grenfell fire has provided stark evidence on the social and political determinants of health inequalities - the direct impact of the conditions of living on health, and the need for appropriate upstream policies, including action by national and local government to deal with the housing crisis in this country. ${ }^{10,11}$ Giving marginalised and disadvantaged people a voice so that their concerns and views are heard by those in positions of power is essential. Political processes and decision making also needs to be more open and accountable so that the needs of local populations, often very diverse backgrounds, are heard and responded to.

Speaking truth to power is a fundamental tenet of public health advocacy. In August 2016 the Joint Strategic Needs Assessment (JSNA) for Kensington and Chelsea focused on housing as a local public health priority, ${ }^{12}$ but publication of this report clearly did not avert the subsequent disaster one year later. Public health professionals and other agencies need to be empowered and independent to challenge threats to the health of their local populations. Lastly, the underlying importance of effective regulation and legislation in improving the conditions of daily living needs to be recognised and strengthened. Housing, work places, schools, hospitals and other settings of modern life all need to comply with up-to-date and stringent regulations to ensure their safety and the promotion of health and the well-being of the people living, working and using these settings. This is important for the whole population but particularly for the most vulnerable in society. 
The Grenfell Tower fire has been a wake-up call for British society in many different respects. Urgent changes are needed to ensure that the lessons learnt are acted upon to avoid such a tragedy ever happening again.

1. Whitehead M. The concepts and principles of equity and health. Int J Health Serv. 1992; 22: 429-445.

2. McKee M. Grenfell Tower fire: why we cannot ignore the political determinants of health. BMJ 2017; 357: j2966. DOI: 10.1136/bmj.j2966.

3. Chakrabortty A. Over 170 years after Engels, Britain is still a country that murders its poor. The Guardian. 2017. Available at https://www.theguardian.com/commentis- free/2017/jun/20/engels-britain-murders-poor-grenfelltower (accessed August 2017)

4. Davis R, Pless B. BMJ bans 'accidents'. BMJ 2001; 322 1320-1321.

5. Rose G. Rose's strategy of preventive medicine. Oxford: Oxford University Press, 2008.

6. London's Poverty Profile. New analysis of poverty in Kensington and Chelsea. [Internet]. Trust for London, New Policy Institute [cited 2017 Jul 19]. Available at http://www.londonspovertyprofile.org.uk/news/updated-profile-of-kensington/ (accessed August 2017).

7. Public Health England. Kensington and Chelsea Health Profile 2016. UK Government. Available at http://www. psnc.org.uk/kensington-chelsea-and-westminster-Ipc/ wp-content/uploads/sites/73/2017/05/2016.pdf (accessed 12 September 2017).
8. Edwards P, Green J, Roberts I, Lutchmun M. Deaths from injury in children and employment status in family: analysis of trends in class specific death rates. BMJ 2006; 333: 119-121.

9. Marmot M, Bell R. Social determinants and dental health. Adv Dent Res 2011; 23: 201-206.

10. Marmot M. Fair society, healthy lives: strategic review of health inequalities in England post - 2010. London: Department of Health, 2010.

11. Sheiham A. Improving oral health for all: focusing on determinants and conditions. Health Educ J 2000; 59: 64-76.

12. City of Westminster and Royal Borough of Kensington and Chelsea. Housing support and care: integrated solutions for integrated challenges. Joint Strategic Needs Assessment (JSNA), 2016. 